\title{
The Political Process in the Preparation ofPublic Policy A Case Study on the Preparation of the Constitution of Oil and Gas in the Republic of Indonesia's House of Representatives
}

\begin{abstract}
Julizar, IDRIS
Doctoral Program of Public Administrative Science, Faculty of Administrative Science, Brawijaya University, Malang, East Java, Indonesia yoxxe1308@gmail.com Abdul, HAKIM
\end{abstract} Department of Public Administrative Science, Faculty of Administrative Science, Brawijaya University, Malang, East Java, Indonesia abdulhakim@ub.ac.id

Sarwono, SARWONO

Department of Public Administrative Science, Faculty of Administrative Science, Brawijaya University, Malang, East Java, Indonesia sarwono@ub.ac.id

Bambang Santoso, HARYONO Department of Public Administrative Science, Faculty of Administrative Science, Brawijaya University, Malang, East Java, Indonesia bambangsfia@ub.ac.id

\begin{abstract}
Public policy formulation as a political process is a dynamic formulation of policies involving many actors, ranging from the executive, legislative, academic, to non-governmental organizations. The purpose of this study was to find out the political process of drafting the Oil and Gas Law and determine the model for the formulation of the Oil and Gas Law in the Republic of Indonesia's House of Representatives. This research method uses a qualitative approach, through observation, in-interview techniques and documentation of secondary data in the process of collecting data. Data analysis using the Interactive Model method by Miles \& Huberman's. The results of the study indicate that the political process of drafting the Constitution of Oil and Gas takes place in the following stages: planning, drafting and discussion. Politically, the planning of the Constitution of Oil and Gas comes from several sources: (1) the bill from the President; (2) the bill from the House of Representatives; and (3) the bill from the Regional Representative Council.The long political process in the public policy formulation in the House of Representatives starts from the process of inventorying input from factions, commissions, and the public to be determined as a Legislative Body decision, then the decision is to be consulted with the Government; afterwards, the results of the consultation are reported to the Plenary Session to make the decision.
\end{abstract}

Keywords: Oil and Gas Law, Political process, Public policy, Republic of Indonesia's House of Representatives

JEL Classification: D72, D73, J18, P16. 


\section{Introduction}

Policy is a collection of decisions taken by an actor or political group in an effort to choose the goals and ways to achieve them (Dunn, 2003). Fundamentally, those who make these policies have the power and authority to implement them. The connection between policy and politics is also explicitly expressed in Budiardjo's view, stating that policy is one of the concepts in political science (Budiardjo, 2009: 2), and therefore public policy cannot be separated from the political process taking place in its formulation and also in its implementation.

The relevance of that particular view with this research has something to do with the political process in the formulation of public policies, especially policies in the energy sector, and more specifically the constitutions governing oil and gas. At present, the actors involved in the formulation of energy policies are mostly from the Government (the executives) and a small number of entrepreneurs. Various groups involved as policy users are often disregarded. On one side, mass media is only used as a tool to politicize policy; even sometimes policies that have not been final and become state decisions are often leaked to the public, resulting in a blunder of opinions and various protests inflicting impacts as well as making the socio-cultural aspects stronger than the substance of the constitution. This is in accordance with what Mitchel and Gibson (2011) stated: "In terms of policy making, first, my fundamental belief is that the policy process is never totally rational, but always informed and shaped by politics".

Energy policies implemented by a country or organization are inseparable from various problems. An example of a fundamental problem with energy policy was put forward by Deutch (2011), stating that there are several factors playing an important role in policy formulation, but are not taken into account and eventually become a problem. These factors are: first, the goal; this does not mean that the rules have no goals to achieve, but it is more to the substance of the goal. So far, the purpose of the energy policy that has been made is without considering various important aspects, and is not comprehensive; thus, the goal has not been achieved. Second, public opinion and moral attitudes. The public's concern about energy problems has been increasing since the 1970s. There are three things related to public opinion and morality: (1) there is an increase in the number of society showing concern for the country's energy future; (2) energy costs, weather changes, and energy security are the main concerns of today's society; and (3) the public is more open to the steps of energy conversion and new technology. Community attitudes towards energy also differ in one country 
and another. This is due to dissimilarities in the adoption of efficient principles or equality principle in guiding national emission restrictions.

Based on the explanation, in the framework of creating Indonesia's energy security, it is clear that the management of natural wealth in the form of oil and gas requires a "better" legislation adopting the dynamics of change that occurs in society and in the business world. According to Nugroho, an important component in a modern country is public policy. Every modern country is ensured to have a constitution, laws and regulations, as well as policy decisions as the rules of socially collective life. A country without a component of public policy is a failed country, because the shared life is governed by a group of people working like tyrants to satisfy their own interests and / or groups (Nugroho, 2014).

The problem often occurs in the process of drafting the constitutions is that a large number of them are arranged on political grounds and interests in the House of Representatives, and some articles in certain rules are even removed. In the general drafting process, it has become the right and authority of the House of Representatives. However, on the basis of democracy, the community, NGOs, Universities, CSOs, need to guard the drafting process. In the process of revising the Constitution No.22 of 2001 concerning Oil and Gas (the Constitution of Oil and Gas), which is the case in this study, it has become a National Legislation Program from 2001 to 2015, but it was stagnant and the discussion process stopped. This was because of the profound interests of the Government, businessmen, political elites in the process of formulating and resolving the Constitution of Oil and Gas. This occurred due to the unfinished political process problems in the House of Representatives, both in discussions and review plans. Therefore, it is very essential and relevant to examine the political process of drafting the Constitution of Oil and Gas in the House of Representatives of the Republic of Indonesia.

\subsection{Theoretical Review}

Public policy is the rules made by the government and is a part of political decisions to overcome various existing and developing problems and issues in the community. Public policy is also a decision made by the government to choose, to take or not to take certain actions. People living within the jurisdiction of a country often undergo various problems. Countries that hold full responsibility in the lives of their people must be able to solve these problems. Public policies made and issued by the state are expected to be a solution to these problems. According to Mustopadidjaja, public policy is a decision that is intended for the purpose of overcoming problems that arise in certain activities 
carried out by government agencies in administering the government (Mustopadidjaja, 2002).

Nugroho (2014:42-43), states that there are two streams of understanding of public policy. First, the Continental Stream, which sees public policy as a derivative of law; sometimes it even puts public policy in the same position as law, especially public law or constitutional law, so this stream perceives public policy as a process of interaction between state institutions. According to the continentalists, law is a form of public policy, both in terms of entity and product, as well as in terms of process and content. Regarding 'product', since public policy can be in the form of a law, it can also be a convention or agreement. At a certain level, it can even be in the form of public officials' oral decisions or conducts. As to 'process', law is a product of the state or government; so the people or the public are positioned more as the recipients of the product or are affected by of the state behavior. Legal formulation does not require public involvement in the process.

The second stream of understanding is the Anglo-Saxonis, which tends to understand policy as a derivative of political-democracy. Thus, this stream sees public policy as a product of interaction between the state and the public. Public policy is a product upholding the public interest, whose philosophy is to require public involvement from the beginning to the end.

According to Nugoroho, the constitution in Indonesia, as one of the most important forms of public policy, is understood as a product of the legislature and executive, eliminating the existence of the public at the core of the process. Thus, the constitution is only understood as a product of the legislature (the House of Representatives) and authorized by the executive (the President) (Nugroho, 2014).

Howlett and Ramesh (1995) state that actors involved in the process of public policy formulation can be individuals. There are five main categories in it, namely: elected officials, appointed officials, interest groups, research organizations and mass media. Indonesia has a different system of government compared to the perspective of Howlett and Ramesh that distinguishes its policy system. In Indonesia, its public policy system includes political infrastructure and political superstructure. Political infrastructure includes political parties, interest groups, mass media and citizens. While the political superstructure consists of elements of the People's Consultative Assembly, the House of Representatives, the Supreme Court and the State Audit Board (Islamy, 2003).

The process of public policy formulation involves many actors. To understand the process correctly, it is necessary to identify the main actors, both individuals and groups, as well as organizations, so that it is easy to explore and 
examine the patterns of interaction and their preferences. The identification of policy actors can be carried out through careful formulation of policy space, which is then linked to the policy issue areas usually containing a number of overlapping policy spaces. The policy space itself is indicated by the existence of several particular actors whose presence is relatively stable; also, their preferences, predispositions and interests towards a particular policy are easily seen (Abdul Wahab, 1999). The policy room has a 'entry point' function to understand the broader political environment, while the area of policy issues is part of the political environment directly related to the policy to be analyzed.

The process of policy formulation is a social event and an arena of struggle for interests. Therefore, when the process begins, each actor involved tends to take a certain position on the policy plan being rolled out. In such situation, they will interact and communicate in order to obtain support from other actors in order to make their interests accommodated in the policy plan.

Policy Actors and Policy Institutions have very close attachments, especially in the process of policy formulation. Howlett and Ramesh (1998: 52), stated that actors in the policy process might point to individuals or groups, in which this pattern of behavior is involved in certain conditions as a policy subsystem. Howlett and Ramesh divided policy actors into five categories, namely: (1) elected officials, which are the executive and legislative; (2) appointed officials; (3) interest groups; (4) research organization; and (5) mass media.

The issue often debated is the opposition between public policy and public law. According to Nugroho, two approaches can be utilized to study these two: the academic approach and the pragmatic approach. First, the academic approach; it emphasizes the political system for the reason that the game rule in the life of a modern state is politics. The product of a political system is public policy, because public policy is an institutionalized political decision (Nugroho, 2014: 65).

As a product of the political system, public policy has four forms, they are: (1) the formal policies or formal regulations; (2) the common practices of public institutions that have been mutually accepted (conventions); (3) the statements of public officials in public forums; and (4) the public officials' conducts. Whereas formal policies have three forms: (1) Legislation (Act): Constitutions, Government Regulations in lieu of laws, and Regional Regulations; (2) Law: Criminal Law, Civil Law, Religious Law; and (3) Regulation: Government Regulations, Presidential Regulations, Ministerial Regulations, Regional Head Regulations. The three forms of formal policy can be explained as follows: first, legislation is public policy relating to national development efforts, in regards to 
both the state and society. As it has something to do with development, the legislation is usually actuating, dynamic, anticipating, and making room for innovation. Second, the law deals with order, and if needed, one with rigid discipline. Order is related to efforts to limit and prohibit. The law also includes legal decisions, which consist of: (a) mediation decisions or agreement decisions between the parties to the dispute; (b) court decisions or decisions made by the judge through a judicial process; and (c) judicial decisions or decisions made by institutions above the court decision makers, for example the Supreme Court Decision. Third, regulations relating to the allocation of assets and state power by the Government as representatives of state institutions, to non-government parties, including business and non-profit institutions. General regulations are the granting of licenses to a business organization.

The second approach is a pragmatic approach, which states that law is a legal forum for public policy. This approach explains that public law is part of the final process of public policy because on the one hand, it provides a legal forum for the state to achieve the objectives brought by public policy; while on the other hand, it is a form of limiting state power since the principle of a modern state is a country with unlimited power.

According to Nugroho, it can be said that public law is the formalization and legalization of public policy. Without formalization and legalization processes, public policy is "powerless" to be implemented (Nugroho, 2014: 70). Furthermore, Nugroho (2014) explained that there is a red thread between public policy and public law. First, public policy is not synonymous with law, because public policy is not always in the form of law. Second, if the law is to punish and to limit, then the public policy is to direct, to guide, and to govern. Third, public policy does not rule out the law, because law is an arrangement and a formal form of public policy.

According to Nugroho (2014), the policy process as a law always begins with a political process, followed by a policy process, a law making process, and ends with a process of standardizing public policy as a law. Nugroho compared these four processes to the process of making bread. The political process is like the process of collecting all raw materials for making bread. The policy process is like processing all raw materials, stirring the mixture to expand; and after expanding, the batter can be shaped as needed. The legal process is the process by which the batter has been expanded and cut as desired. At the time of implementing the policy, it is like putting the batter into the oven and baking it into bread. The purpose of the law is to make public policy workable and to limit the power of the public policy makers and implementers. 


\section{Research Methods}

The overall focus of this study uses a qualitative approach, through observation, in-depth interview techniques and documentation of secondary data in the process of collecting data. The collected data were tested for validity and reliability using credibility (internal validity), transferability (external validity), dependability (reliability), and confirmability (objectivity) tests (Sugiono, 2013). Afterwards, the data were analyzed using the Interactive Model method (Miles, et al., 2014), with data analysis components consisting of: data collection, data condensation, data display, and conclusions (Figure 1). Through the use of this method, the researchers formulated data-based theoretical propositions, as well as empirical models of political processes in public policy formulation.

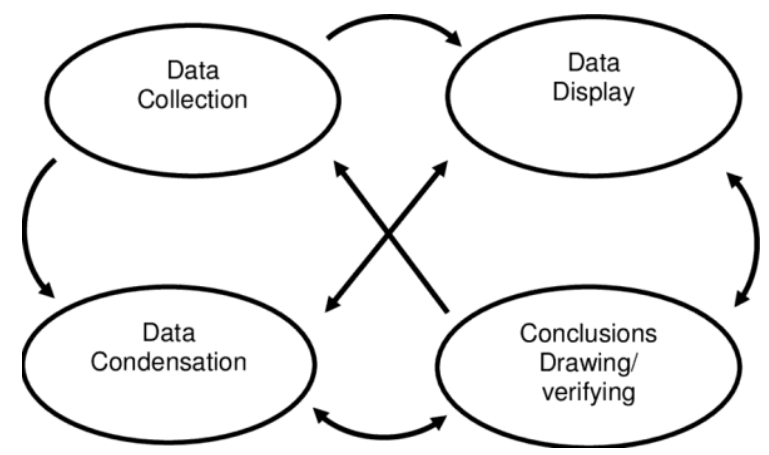

Figure 1. Data Analysis: Interactive Model

Source: Miles, Huberman and Saldana (2014)

\section{Research Results and Discussion}

The Constitution of Oil and Gas has an important role in regulating all aspects of oil and gas management without exception and end-to-end. There are several aspects that must be immediately resolved in the Constitution of Oil and Gas, one of which is that the position of the state in the use of natural resources must be strong. In other words, ownership rights to oil and gas are in the state and the state itself must benefit from it. Furthermore, changes to the Constitution of Oil and Gas must aim to increase production. In addition, the new rules in the oil and gas sector can attract investors to put investment in Indonesia and not the other way around, which is making the investors feel apprehensive. The provisions contained in the Constitution of Oil and Gas revision should be related to forestry, environment, shipping, taxation, central and regional financial balances, and investment; not a longer and more complicated 
contractual cooperation procedure. The complexity of the problems along with the number of parties and sectors involved in them has made drafting the Constitution of Oil and Gas immensely loaded with political content and interests which greatly affect the accomplishment of oil and gas management which brings welfare to the society.

\subsection{Planning}

Political Planning for the Constitution of Oil and Gas is derived from several sources, namely: (1) The bill from the President; (2) The bill from the House of Representatives; and (3) The bill from the Regional Representative Council. The political process occurs as there are many interests in the preparation of the planning process.

This constitution even has been repeatedly revised by the Constitutional Court and the House of Representatives.In addition, it also involves many stakeholders, each of whom gives an opinion on the revision of the planned Constitution of Oil and Gas. The discussion is related to the meaning of the sentence "controlled by the state", which is derived from the constitutional mandate in Article 33 of the 1945 Constitution. This occurs because in political perceptions, the control over natural resources is considered as the authority of the government; but in its implementation, it is used for the benefit of a few people only. This is what causes this Constitution of Oil and Gas to be submitted by the executive to be regulated in the Constitution of Oil and Gas. The right to control natural resources by resource economists is recognized as the right of bundle, because the word 'control' actually contains four meanings (Pudyantoro, 2012: 107). This 'control' is arranged in stages starting from the lowest level to the highest level, as follows: (a) Use Right (right to use): the right or control to use natural resources which is limited to the right of using the land in accordance with the allotment mutually agreed; (b) Management Right (right to manage): the power holder not only can use, but also has the right to manage. Management means the right to organize and the right to decide on its use; (c) Transfer right: ownership rights can be transferred. The transfer of rights can be done for part or all rights depending on the agreement with the power of attorney grantor; and (d) Ownership: the highest right of control of natural resources is the right to own, because the owner can use, manage and also transfer these rights.

Rahyani (2014: 62-63) stated that the Constitution of Oil and Gas must be prepared because the state's control of oil and gas must be legalized in a constitution. Oil and gas is a production branch that is important for the state as well as controls a large number of people's livelihoods, and is the natural wealth 
contained in Indonesian earth and water which must be controlled by the state and used for the greatest extent of the people's prosperity as meant in Article 33 paragraph (2) and paragraph ( 3 ) of the 1945 Constitution.

The Constitutional Court has given meaning regarding state control in Article 33 of the 1945 Constitution, that state control in Article 33 of the 1945 Constitution has a higher or broader sense than ownership in the conception of civil law. The concept of 'controlled' by the state is a conception of public law relating to the principle of popular sovereignty adopted in the 1945 Constitution, both in the fields of politics (political democracy) and economics (economic democracy). In understanding the sovereignty of the people, it is the people who are recognized as the source, owner, and also the highest holder of power in the life of the state, in accordance with the doctrine: "from the people, by the people, and for the people".

Based on Article 33 paragraph (2) and paragraph (3) of the 1945 Constitution, the definition of being controlled by the state must convey the meaning of controlled by the state in a broad sense, which is sourced and derived from the conception of the Indonesian people sovereignty over the resources of the earth, water and natural resources contained in it.

This also includes the notion of public ownership by the over the sources of wealth at issue. The people collectivity are constructed by the 1945 Constitution giving a mandate to the state to implement policies (beleid) and management actions (bestuurdaad), regulation (regelendaad), management (beheersdaad), and supervision (toezichthoudensdaad) for the purpose of maximizing people's prosperity (Court Decision Constitution Number 36 / PUU-X / 2012, November 13, 2012, p. 98).

From the five phrase concepts controlled by the state, as established in the Constitutional Court's decision, namely: policy, management, regulation, management, and supervision; only a regulatory concept that explicitly mentions the involvement of people's representative institutions such as the House of Representatives. This is because it is seen as the institution of legislation, and it also pertains to budget institutions and supervision institutions. The current constitutional conception of being controlled by the state, as interpreted by the Supreme Court in its decision, have two concepts, namely: first, the management function is carried out through a share ownership mechanism and / or through direct involvement in the management of state-owned enterprises or stateowned legal entities as instruments institutions, through which the government must conduct institutional relations with the representative institutions of the people, namely the House of Representatives, the Regional Representative 
Council, and / or provincial / district House of Representatives (the Regional House of Representatives), in utilizing their authority over the sources of wealth to be used to the greatest extent of the people's prosperity. The second concept is the state supervision function carried out by the state c.q. the government in the framework of supervising and controlling, so that the implementation of control by the state over the important branches of production and / or which controls of many people's livelihoods is really intended for the greatest prosperity of the people (Erman Radjagukguk, the Results of the Public Hearings Bill on Oil and Natural Gas, Tuesday November 27th 2017).

The next finding in the planning process is related to the priority scale in the National Legislation Program, which makes the Constitution of Oil and Gas consumes quite a long time to finally become a constitution and be free of polemics. In addition, there is an assumption that the formation of the Constitution of Oil and Gas sourced from the National Legislation Program still cannot fulfill the prioritized and measurable needs. Whereas, it is known that the Government as the holder of mining rights has an interest in having a strong legal basis in the management and exploitation of the oil and gas sector, so that it can fulfill the mandate of Article 33 of the 1945 Constitution. Good management of oil and gas resources will provide two benefits at once, namely: first, increasing the state revenues; and second, having a multiplier effect on the economy.

Therefore, according to Pudyantoro, the upstream oil and gas business can be carried out by the Government by fulfilling the following requirements: (a) the control of oil and gas natural resources remains in the government; (b) the government does not bear the risk of not finding oil and gas reserves; and (c) the government does not encounter funding difficulties, funds are always available anytime and in unlimited quantities because petroleum operations deal with a lot of uncertainty (Pudyantoro, 2012: 14).

Another problem sparking a discussion in the planning process is about production sharing contracts (PSC). This term is found in Article 12 paragraph (2) of the Constitution No.8 of 1971 concerning Pertamina, in conjunction with the Constitution No.10 of 1974 concerning Amendment to the Constitution No.8 of 1971 concerning Pertamina. Pertamina itself is the holder of mining rights over all mining jurisdictions in Indonesia, as far as oil and gas mining is concerned. In its implementation, Pertamina, which due to lack of capital and technology, is able to cooperate with other parties in exploring and exploiting oil and gas mining in the form of production sharing contracts. 
The definition of profit sharing contracts based on Article 1 no.1 of the Government Regulation No.35 of 1994 concerning the Guidelines for Cooperation in Oil and Gas Production Sharing Contracts, is a collaboration between Pertamina and the Contractor to carry out business of exploration and exploitation of oil and gas based on the principle of production sharing (Article 1 no. 1 of the Government Regulation No. 35 of 1994 concerning Terms and Conditions of Guidelines for Cooperation in Oil and Gas Production Sharing Contracts).Whereas Article 1 no.19 of the Constitution of Oil and Gas, a cooperation contract is a production sharing contract or other form of cooperation contract in exploration and exploitation activities that benefits the country more and the results are used for the greatest prosperity of the people (Article 1 of 19 of the Constitution No. 22 of 2001 concerning Oil and gas). This material is the starting point of reference for the revision of the Constitution of Oil and Gas, because one of the important parts of oil and gas business activities is the establishment of models and employment contracts for oil and gas business as the oil and gas industry is capital intensive and has a high risk. Production sharing contracts are a form of cooperation with foreign parties in the oil and gas sector which must describe the principles of oil and gas exploitation in accordance with the constitution and legislation.

Sumantoro defines the production sharing contract agreement as a collaboration with a revenue sharing system between state companies and foreign companies that are contractual. If the contract expires, the machines brought by foreign parties will remain in Indonesia. Collaboration in this form is an external credit whose payment is made by means of profit sharing on the production produced by the company (Inosentius, 2014: 34). In simple terms, it can be said that the principle of profit sharing is the principles governing the sharing of profits obtained from oil and gas exploitation and exploration activities between the implementing institution and the permanent business institution. The profit sharing is then negotiated between the two parties and set forth in the PSC. The duration of planning - drafting - in the revision of the Constitution of Oil and Gas, among others, is also due to the search for a pattern that is favorable for the state, in terms of production-sharing contract agreements with foreign investors. A country's oil and gas industry is different from each other in terms of how the roles and responsibilities of the three functions are regulated, namely: policy, regulation, and commercial (business) functions.

Some countries clearly separate these functions, such as: Norway and Brazil. In Norway, the policy function is handled by the Ministry of Petroleum and 
Energy, the function of regulation under the Directorate of Petroleum and commercial functions is carried out by the National Oil Company (NOC) together with the IOC (International Oil Company). Similarly in Brazil, the three functions are clearly separated.In some countries, there is no clear separation of the three functions; instead, one concurrently functions the other. In Saudi Arabia and Malaysia, for instance, the NOC (Saudi by Aramco and in Malaysia by Petronas) plays a very dominant role. So, aside from acting as a commercial function, it also plays a regulatory function. In contrast, Venezuela's Ministry of Petroleum plays a more dominant role. While in Iran, the dominance between NOC (National Iranian Oil Company / NIOC) and the Ministry is relatively balanced. In developing countries, the commercial role is generally carried out by the NOC, alone or together with the IOC. While in OECD (Organisation for Economic Cooperation and Development) countries, among others: USA, UK, Australia and Canada, the state do not go directly into the oil and gas business through the NOC (there are no NOCs in these countries), so commercial functions are purely carried out by private parties.

The Indonesian PSC model is divided into 85\%: 15\% (oil) and 70\%: $30 \%$ (gas) for full cycle activities, from exploration to production. Compared to other countries, the revenue sharing including the tax is already quite good. What happened in Bolivia and several other Latin American countries was actually inseparable from the unfair contract made in the past. The 1997 Constitution of Oil and Gas in Brazil, related to the arrangement of cooperation with investors in the context of exploration and exploitation activities, only mentions the concession system. The constitution does not mention the possibility of using a system other than concession. Therefore, the PSC system has never existed, so the authorities in Brazil began to examine the contract system used by other countries which led to debate over two choices: to continue using the concession system with modifications or to move to the PSC system. The debate raises the pros and cons of academics; those who still want the concession system argue that this system has been successful for decades, if the government feels the need to obtain a larger portion, it can be done by making slight modifications without having to move to the PSC system. While supporters of the PSC system assume that the concession system is only suitable for work areas that have a large geological risk. In addition, even though both systems can provide the same portion of revenue for the government, the arrangement of the distribution will be easier with the PSC framework, because there is an element of profit sharing. 
It is clear that what happened in Brazil is the opposite of Indonesia's situation. First, oil and gas exploration activities in Brazil are a huge success, but the opposite situation occurs in Indonesia. Second, Brazil considers the PSC, while in Indonesia the government is busy looking for other systems other than the PSC for cost recovery reasons. So far, Brazil's steps have been appropriate, because the first step for them is inviting investors for oil and gas exploration with attractive terms and conditions. Conversely, Indonesia is too busy looking for contracts that benefit the country; while at the same time, exploration performance is less encouraging.

The comparison of revenue sharing models in several countries has been outlined in an academic text that becomes a reference for the revision of the Constitution of Oil and Gas. Thus, the planning of the Constitution of Oil and Gas is based on the academic text of the constitution on oil and gas. This academic text is a theoretical framework which is a rationale for producing a product of constitutions on oil and gas as a political product. The theoretical framework or rationale for drafting a constitution on oil and gas is needed as a guidance, so that what is explained in the theoretical framework or thought framework is in accordance with what will be regulated in the content of a constitution.

The planning for drafting the Constitution of Oil and Gas is a legal political area since it is a rule of law produced from or by a political process. Rules of law that are made from a political process are constitutions. A constitution can be referred to as legal politics, because it is produced in a political process between the legislature and the executive. A constitution is also a political decision that can force all levels of society, including political institutions (legislative institutions, executive institutions and the judiciary) to comply with the rules of law in the constitution.

Viewing from the aspects of public policy formulation, the discussions take place in the policy planning process; as previously discussed, whether the political process is fast or slow is determined by the pattern of support provided by stakeholders on the Constitution of Oil and Gas which will be revised. According to Howlett and Ramesh (1995), the typology of policy in the agendasetting phase is determined by the pattern of support from the public in defining the problem. Therefore, it can be the initiatives from the outside, initiatives from the inside, consolidation or mobilization. In the phase of typological policy formulation, the policy is determined by rules or patterns of interaction of the policy subsystem; therefore, it can be a hegemony, order, small leadership or anarchist. In the typology decision-making phase, the policy is determined by the complexity of the policy system. Thus, it might be incremental, satisfying, optimized or rational. In the typology implementation phase, the policy is 
determined by the complexity of the policy subsystem and administrative capacity of the policy scope at issue; so, it can be market-based, regulatory, subsidy or voluntary.

\subsection{Preparation}

In the previous chapter, it was concluded that: first, the political process of drafting the Oil and Gas Bill / Constitution was carried out through: (1) compiling academic texts; (2) preparation; and (3) harmonization and synchronization.

Secondly, the Constitution of Oil and Gas compiled by making academic texts is a procedural step that is not easy to go through, because this activity is a scientific study and also because there are many interests with their own perspectives; that is, the parties outside the House of Representatives and executives have their own perspectives in viewing the Constitution of Oil and Gas, and these also includes NGOs and the wider community.

Third, there are several things that make the drafting of the Constitution of Oil and Gas need to be rearranged, namely: (a) the situation of increasing global economic uncertainty affecting the domestic economy; (b) being a political product, many interests pulling around each other making the political process of changing the Constitution of Oil and Gas becomes hampered; and (c) the drafting of the Constitution of Oil and Gas has a very strong political challenge because of the strong pulling around by many parties: the Government, Parliament and the wider community.

The model of making the National Legislation Program is made more open, but is not made as a public debate in the context of public policy formulation; which usually takes a long time and is held in a participatory manner, such as the establishment of the National Legislation Program in the previous years. It is rather a collection of lists from the Government, the Regional Representative Council, commissions in the House of Representatives, and interest groups (non-governmental organizations, study institutions, etc.). As a result, it is simply the collection of titles list without any explanation of the public issues that is to be formulated into a policy plan, and without considering the urgency level, macro implementation plan, and policy evaluation plan. Whereas, as Easton stated (quoted by Islamy, 2000), as public policy is a form of allocation of values, it should be objective and well structured, since the public has a very large interest in the impact of policies. Thus, the efforts to formulate public policy are not just to collect a "list of policy titles" to be formulated, but there should have been initial drafts, including the existing academic texts. 
The Constitution of Oil and Gas in National Legislation Program must correlate with the overall development planning. In terms of making the National Legislation Program, it must be constructed as a debate on the formulation of public policies in a participatory and open manner. Legislation is a policy process that is dynamic and has a sociological and political nuance. As previously explained, the drafting of the National Legislation Program is carried out by the House of Representatives and the Government in a planned, integrated and systematic manner, of which the implementation is coordinated by the House of Representatives.

The preparation of National Legislation Program in the House of Representatives is coordinated by the Legislation Body. As for the Government, it is coordinated by the Minister whose duties and responsibilities are in the field of legislation. Specifically, the implementation of the National Legislation Program prepared by the Government can be carried out by the National Law Development Institution, because this institution has long existed as a national legal development institution.

The performance of the National Legislation Program conducted by the National Law Development Institution should be under the direct supervision of the President which can be coordinated through the relevant ministers. This program is substantial because it is a national program involving various institutions, government institutions and legislators. The preparation of National Legislation Program must be organized by an institution as a consideration to be followed up with authority, legitimacy, adequate facilities and infrastructure to coordinate (both between government agencies and the House of Representatives Legislation Body), and must synchronize a planned, integrated and systematic National Legislation Program as well, in order to support the realization of a national legal system that serves national interests.

In addition, ethical and moral issues in the formulation of constitutions in Indonesia must also be considered since the drafting stage of the National Legislation Program until the implementation of legislation, and its implementation within the society. Ethical and moral crises occurring in both stages, that are very important, critical and strategic in the development of this nation and state, largely determine the form and character of the legislation produced as well as the conditions of the society and nation that will be formed with the law. Ethics and moral formation of national law in a democratic governmental system are fundamentally different from an authoritarian governmental system. In a democratic governmental system, ethics and morals can be measured by three things: human rights, justice, and community accessibility into the National Legislation Program (Suseno, 2000: 45-46). 
The three ethical and moral benchmarks of the the national law formulation are the determinants of how far the politics of national legislation has implicitly considered the ethics and morals of legal development. In terms of human rights, the ethics and morals that should be built and maintained are those in line with the foundation of the aspired political life in the opening of the 1945 Constitution; and in particular, they must thoroughly refer to the Second Amendment of the 1945 Constitution Chapter XA concerning Human Rights.

In terms of justice, ethics and morality in the formulation of national law should provide everyone's right proportionally according to their obligations to participate in implementing and maintaining the administration of the state. Whereas in terms of community accessibility to the National Legislation Program, specifically the Constitution of Oil and Gas, community empowerment of rights and obligations is required in accordance with the prevailing constitutions and understanding that community empowerment must be accompanied by an increase in legal culture including community legal awareness. On the other hand, the accessibility of the community must also be supported by an awareness in increasing the understanding of bureaucracy related to their role as a model that can provide good examples in obeying all prevailing laws and regulations (Atamasasmita, 2003).In the context of the three benchmarks of ethical and moral problems in the formulation of national law, the application's effectiveness of the Indonesian nation's views of life including philosophy, vision and mission of the existence as a people and a nation, is a measure of the success of national legislation politics.

In this case, quantitative and normative-qualitative measures are not the only benchmarks to be considered in assessing the effectiveness of resolving the bill by the House of Representatives and the Government each year; the community and political culture aspects are also needed to be considered, especially since the era of reformation was manifested. This is because the legislative process of product legislation is not a process sterile from political interests, as it is a political process. Even the implementation of legislation, known as "law enforcement", is also not always sterile from the influence of legal politics that is material / substance law or legislation. As it is generally understood, legal development is basically the construction of a legal system.

As presented in the previous chapter, there are a number of things that have caused the drafting of the Constitution of Oil and Gas to be rearranged: first, the increasing global economic uncertainty situation. Second, as a political product, the discussion of the bill in the House of Representatives should go more effortlessly because the composition of the House of Representatives is now controlled by a coalition supporting the government. However, the 
discussion has not finished because of the different political interests of the House of Representatives' various factions and the external influences.

The number of internal and external influences in policy making is explained by Nugroho (2014) as a political process in the preparation of public policy. According to Nugroho, the political process of policy making does not see the existence of individual actors, but many actors with many issues and strategies; because they act according to the rational concept assuming that the actors have the freedom of opinion, concept, responsibility and claim that their opinions are true. Handling this issue is manifested in the process of bargaining between actors, or arguing, competing alternatives, persuading to making coalition, until reaching the decision. The success of the policy implementation is highly dependent on the support of each supporter's power and skills, as well as the output which is policy products, supported by a solid political system.

Based on these descriptions, it can be said that the drafting of the Constitution of Oil and Gas has a very strong political challenge because of the strong pulling around by many parties: the Government, Parliament and the wider community, including in the preparation of the Constitution of Oil and Gas which is being revised. The process of bargaining among these various interests has no meeting point because some parties claim that their opinions are the most correct; thus, no decision is made.

\subsection{Discussion}

The discussion of the Constitution of Oil and Gas in practice, as the findings presented in the previous chapter, is very strong in terms of its legal politics. According to Wahjono (2007: 45-46), legal politics is a basic policy that determines the direction, form and content of the law to be formed.

Legal politics is the policy of state administrators about what is used as a criterion to be determined as a law of something, which includes the formulation of law, the application of law, and law enforcement. Based on this formula, it can be said that the legal politics of oil and gas management in Indonesia is participating in providing inputs for the efforts to establish the Constitution of Oil and Gas products needed both at the national and regional levels in the future or as aspired (ius constituendum) based on the dynamics of the society's aspiration with the sovereignty of the people.The political development of the law on oil and gas in Indonesia rests on the development or improvement of existing oil and gas legal products (ius constitutum) or constitutional law products, or legal products of conducts developing in the community, in order to achieve their aspirations in accodance with the mandate of the 1945 Constitution. In this case, the word "legal politics" refers to the prevailing positive law relating to laws and 
regulations governing oil and gas in Indonesia as legal products made by state administrators and the direction of legal developments to be constructed, so it includes ius constitutum (current law) and ius constituendum (the law aspired in the future). In making legislation, legal politics is important in relation to two things: first, to be the reason why it is necessary to establish a statutory regulation. Second, to determine what is to be construed into legal sentences and formulated the article. These two things are important because the existence of legislation and the formulation of articles is a link between the determined legal politics and the implementation of legal politics in the implementation phase of legislation; given that there must be consistency and correlation between what is determined as legal politics and what to achieve as a goal.The discussion phase of the Constitution of Oil and Gas is carried out between the House of Representatives and the President (also with the Regional Representative Council) through two levels of discussion. Level 1 is a discussion at a Commission Meeting, Joint Commission Meeting, Legislation Board Meeting, Budget Board Meeting or Special Committee Meeting. Level 2, is the discussion at the Plenary Meeting. The discussion of the Constitution of Oil and Gas takes place in the first level. This concerns the legal aspects of oil and gas regulation, covering the study area (domain) of state institutions of legal politics, legal political location, factors (internal and external) that influence the political development of the Constitution of Oil and Gas, application level in the form of implementing legal products which is the political consequence of the legal politics and aspired laws. The legal aspects of oil and gas regulation also use the process of exploring the values and aspirations developing in the community by the state administrators who are authorized to form legal politics. There are factors that influence and determine a legal politics; whether it has been, is being, or will be defined. This can be used to assess the implementation of legal politics, resulting in the legal politics of oil and gas according to the needs and welfare of the people; because if the law is built on a foundation that does not correspond to the structure of values developed in the community, there will be community resistance to the law. In regards to this, a good law is one that meets the philosophical, historical and juridical requirements. The above description is in accordance with the public policy formulation theory, which states that the process of policy formulation must incorporate developing opinions in the political community into the agenda of setting policy formulation. The setting agenda is all issues that are generally perceived by political society as public problems and problems involved in the official power of existing government authorities; while the institutional agenda is a series of issues that are explicitly appointed to be actively and seriously considered by decision makers possessing 
the authority.The success of the public problems issue in the agenda setting must go through many tests; among others are winning competing interest, political crisis, shifting issues and priorities held by the policy formulating actors. Meanwhile, the value of the actor's beliefs, adopted ideology, critical life experiences and the influence of mass media also greatly affects the actor's understanding of the problems in the agenda.

After the agenda setting, the next stage is problem definition. At this stage, the problems issue in the agenda is discussed again to determine the next action; the selection of these actions needs to be carried out carefully because it will affect the future. Careful choice of actions includes the forecasting needs and the defining of target groups and areas (Palumbo in Parsons, 1997). Forecasting needs are related to scrutinizing costs predicted to overcome these problems, while defining of target groups closely examines the target group defining and in which area the target group is located.

Generally, it can be said that the process of drafting the Constitution of Oil and Gas is very difficult because it is part of the politics of public policy making. Syirazi (2009: 16), stated that there are three theories that can explain how a public policy is produced. First, the theory of political coalitions and economic interests. According to the theory, political-economic policies are formed because of the pressures of economic groups that have political power to influence the production of a public policy. That is, a political-economic policy is put forth because of political pressure from economic forces that have an interest in legalizing and overseeing the business interests of these economic groups. Based on this theory, it can be said that the product of public policy is not always able to accommodate all public interests of the wider community, because of the existence of stronger and dominant economic forces or groups that legally retain the interests of the group rather than the public interest. This phenomenon is a common thing, especially in transitional societies. Second, the theory of the relative autonomy of the country. According to this theory, the production of a policy product is a reflection of the interests of the state as an actor in the public arena having its own characteristics and choices. The productions of a policy is the result of the efforts of the state to achieve its defined goals. The state in this perspective is not merely an arena where socioeconomic forces compete with each other, but (the state) is also an actor having its own autonomy and logic. Third, the rational choice theory. This theory departs from the basic assumption that every society consists of individuals acting to achieve and maximize their own interests (utility maximizer). 
According to the rational choice theory, public policy is the result of political interaction between rational actors who work to maximize profits or personal interests. Thus, politics is the stage where all parties compete with each other to dredge up existing resources. The strength of this theory lies in its explanation that the state is not an institution filled by bureaucrats, politicians, and technocrats who are free from motives and personal interests; and because of that, state policies will never harm the community (Sheirazi, 2000: 22). Based on the description in the discussion phase, it can be said that the causes of inaction in the discussion process are not only derived from internal factors in the House of Representatives, but also from external sources outside the House of Representatives, that is pulling around interests between those involved in the House of Representatives, in managing oil and gas end-to-end. According to the description above, the propositions can be formulated as follows: The political process in policy formulation takes place since the planning, drafting and discussion stages, and involves many actors from the executive, legislative and judicial branches, which have an impact on the inaction of the policy formulation process, as a result of different views and different goals from each actor toward the substance of the policy to be formulated. The problem found in the discussion stage was the fact that House of Representatives members who filled the composition of the Legislative Body membership did not have enough time and energy to complete their duties because they were very preoccupied with their other parliamentary duties in their respective commissions. This resulted in the discussion of the bill which was often delayed because of the multiple positions between the members of the Legislative Body and the members of the commission, which cause obstruction in the scheduling meetings. In the end, there is often a delay in meeting time because the members often have the two meeting schedules at once, so that the meeting is not punctual or does not meet the quorum. To make the National Legislation Body perform optimally, it is necessary to think of methods for making sure that the members of the Legislative Body are not parts of a commission. Thus, they have enough time and energy to complete the workload in the Legislative Body. One of the methods is that the Legislative Body is occupied by the legal experts in the field of legislation, not the members of the House of Representatives. If the Legislative Body is not occupied by the legal experts in the field of legislation, then it can be assured that there will be no significant changes in the House of Representatives' legislative performance. The House of Representatives members who fill the composition of the the Legislative Body do not have enough time and energy to complete their duties because they have been very preoccupied with their other parliamentary duties in their respective commissions. 
The inaction in the legislative process is also caused by the lack of optimal support from the experts; in some commissions, the capacity of experts is still relatively minimal especially in terms of legislative drafting. In fact, the experts capable in legislative drafting skills is substantial to accelerate the discussion and constitution making.

Viewing the previous description and taking the inhibiting factors in the bill's legislative process into account, a special body is needed; in this dissertation, it is called the Legislative Service Agency, with the main function of providing service assistance to the Commission and the Legislation Body to carry out legal drafting and analysis of The bill proposed by the Government and Parliament. The Legislative Service Agency consists of legal experts and professionals, including retired officials from the ministries who understand the issue of drafting bills as well as understanding the context and substance of the bill being proposed and discussed.

Based on these findings, the recommended model is presented in the following model figure 2 (shown at the end of the paper, after references).

\section{Conclusion and Recommendation}

The political process of drafting the Constitution of Oil and Gas takes place in the following stages: planning, drafting and discussion. Politically, the planning of the Constitution of Oil and Gas comes from several sources: (1) the bill from the President; (2) the bill from the House of Representatives; and (3) the bill from the Regional Representative Council. The political process in planning, drafting and discussing the Constitution of Oil and Gas took place because this constitution was originated from executive initiatives and included in the National Legislation Program; which in its development, many interests were involved in the process of its preparation.

The Constitution of Oil and Gas which has historically been planned and prepared based on executive initiatives, which were later included in the National Legislation Program, has not been resolved to date. It is because the priority of the discussion is based on the needs of the constitution which at that time were urgent, especially when it had something to do with certain political interests. Therefore, comparing between the plans made in the National Legislation Program and the realization of each year, the National Legislation Program always fails to meet its targets. The long political process in the public policy formulation in the House of Representatives starts from the process of inventorying input from factions, commissions, and the public to be determined as a Legislative Body decision, then the decision is to be consulted with the 
Government; afterwards, the results of the consultation are reported to the Plenary Session to make the decision.

The researchers recommend that in order to improve the legislative performance of council members in the process of drafting public policy, an information system is needed to regulate the scheduling of meetings in the House of Representatives, so there will be no overlapping schedules, as a result of multiple positions. In addition, it is necessary to recruit experts who have qualified legal drafting skills to assist the board members and the Commission, or to train the existing experts.

\section{References}

[1] HoAryani, Handayani; dan D. Ariyanti; (2012). "Potency of Solar Energy Applications in Indonesia". Dalam Journal of Renewable Energy Development, Vol.1 (2), 2012.

[2] Atamasasmita, Romli, (2003). Menata Kembali Pembangunan Hukum Nasional. Jakarta: PT.Gramedia Pustaka Utama.

[3] Azhary, Muhammad Tahir, (1995). Negara Hukum Indonesia Analisis Yuridis Normatif Tentang Unsur Umumnya, Jakarta: UI Press.

[4] Azhary, Muhammad Tahir,(1992). Negara Hukum: Studi tentang Prinsip-prinsipnya Dilihat dari Segi Hukum Islam, Implementannya pada Period, Negara Madinah dan Masa Kini, Jakarta: Bulan Bincang.

[5] Aryani, Dewi, (2012). "Skenario Kebijakan Energi Indonesia Hingga Tahun 2035".

[6] Auer, Matthew, (2011). "Energy and environmental politics in post-corporatist Mexico". Policy Studies Journal 29.3 (2011): 437-455 E Journal on-line. Melalui http://search.proquest.com/docview/210558082/ CCBB46773E5 D4002PQ/22? accountid=185286 [05/09/16].

[7] Attamimi, A. Hamid S., (1990). "Peranan Keputusan Presiden Republik Indonesia dalam Penyelenggaraan Pemerintahan Negara", Disertasi, Fakultas Pascasarjana UI Jakarta.

[8] Dye, Thomas R., (1987). Understanding Public Policy. USA: Prentice-Hall, INC., Englewood Cliffs, NJ.

[9] Dunn, William N.; dan Rita Mae Kelly (eds.), (1992). Advances in Policy Studies Since, 1950. New Brunswick, NJ: Transaction Books.

[10] Dunn, William N.; 2003. Pengantar Analisis Kebijakan Publik. Yogyakarta: Gajah Mada University Press.

[11] Howlett, Michael and Ramesh, M., 1995. Studying Puclic Pilicy: Policy Cycles and Policy Subsystem. New York: Oxford University Press.

[12] --------, 1998. "Policy subsystem Configuration and Policy Change: Operationalizing the Postpositivist Analysis of the Politics of Policy Process". In Policy Studies Journal, Vo. 26, No. 3. Pp. 466-481.

[13] Hammond, Emily; Spence, David B., 2016. "The Regulatory Contract in the Marketplace", Jurnal Vanderbilt Law Review, Volume 69, Halaman 141-216 E Journal on-line. Diakses Melalui http://search.proquest.com/pqrl/ docview/1762693441/fulltextPDF/ 27214D7BE9A8449DPQ/2? accountid=185286 [05/09/16].

[14] Islamy, M. Irfan, 2000. Prinsip-prinsip Perumusan Kebijaksanaan Negara, Edisi 2 Cet. 1. Jakarta: Bina Aksara. 
[15] ----------, 2001. Policy Analysis: Seri Monografi Kebijakan Publik. Malang: Fakultas IImu Administrasi Universitas Brawijaya.

[16] Kelsen, Hans, 1995. Teori Hukum Murni Dasar-Dasar Ilmu Hukum Normatif sebagai Ilmu Hukum Empirik-Deskriptif Somardi (alih Bahasa), Jakarta: Rimdi Press.

[17] Knittel, Christopher R., 2012. "Reducing Petroleum Consumption from Transportation". In Journal of Economic Perspectives, American Economic Association, vol. 26(1), pages 93-118, Winter.

[18] Knoepfel, Peter, et al., 2007. Public Policy Analysis. UK: The Policy Press Laughlin, Robert B. (2011).

[19] Kusumohamidjojo, Budiono, 1999. Ketertiban yang Adil Problematika Filsafat Hukum. Jakarta: Grasindo.

[20] Lubis, M. Solly, 2007. Kebijakan Publik. Bandung: CV Mandar Maju.

[21] McJeon, Haewon; Edmonds, Jae; Bauer, Nico; et al. 2016. "Limited impact on decadal-scale climate change from increased use of natural gas", Jurnal Nature Volume 514 Halaman 482 E Journal on-line. Melalui http://search.proquest.com/pqrl/docview/1622369161/fulltext PDF/27214D7BE9A8449DPQ/1 ?accountid=185286. [05/09/16].

[22] Mahfud, Moh., 1999. Amandemen Kostitusi Menuju Reformasi Tata Negara. Yogyakarta: UII Press.

[23] ------------, 2001. Dasar dan Struktur Ketatanegaraan Indonesia. Jakarta: Rineka Cipta.

[24] Miles, Matthew B.; dan Huberrman, A. Michael; dan Saldana, Johnny; 2014. Qualitative Data Analysis: A Methods Sourcebook. Singapore: SAGE Publications Inc.

[25] Nugroho, Riant, 2014. Public Policy: Teori, Manajemen, Dinamika, Analisis, Konvergensi, dan Kimia Kebijakan. Jakarta: PT. Elex Media Komputindo.

[26] Olsen, Kyle K; Mjelde, James W., 2015. "Price formulation and the law of one price in internationally linked markets: an examination of the natural gas markets in the USA and Canada" In Journal The Annals of Regional Science 54.1 (Jan 2015): 117-142 E Journal online. Melalui http://search.proquest.com/pqrl/docview/1656259855/ 78881F46A6D445A6PQ/25? accountid=185286. [05/09/16].

[27] Parsons, Wyne, 1997. Public Policy: An introduction to the Theory and Practice of Policy Analysis. London: Queen Mary Westfield Collage University.

[28] Purbacaraka, Purnadi dan Soekanto, Soerjono, 1989. Perundang-undangan dan Yurisprudensi. Bandung: Citra Adirya Bakti.

[29] Ranggawidjaja, Rosjidi, 1998. Pengantar limu Perundang-undangan Indonesia. Bandung: Mandar Maju.

[30] Ransford Edward Van Gyampo. 2011 "Saving Ghana from Its Oil: A Critical Assessment of Preparations so Far Made", Journal Africa Today, Vol 57.4 : 48-69,136. E Journal on-line. Melalui http://search.proquest.com/ pqrl/docview/883393209/fulltext/ A4994998 AC1A4E2BPO/1? accountid=185286. [05/09/16].

[31] Simon, Herbert A., 2004. Administrative Behaviour. New York: MacMillan.

[32] Suharto, Edi, 2012. Analisis Kebijakan Publik: Panduan Praktis Mengkaji Masalah dan Kebijakan Sosial. Bandung: Alfabeta. 
INTERNAL MEETING OF THE COMMISSION

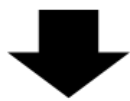

PREPARATION

- Working Team Meeting with Expert Team

- Preliminary research and data collection

- Preparation of Academic Scripts and Initial Draft of the Bill

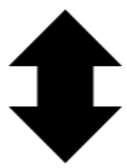

THE LEGISLATIVE SERVICE AGENCY (Expert: Legal and Professional Expert)

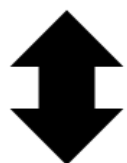

HOUSE OF REPRESENTATIVES PLENARY

- Legalization

FORMULATION

- Seek input from the public and experts

- Domestic work visits (discussions with stakeholders/academics

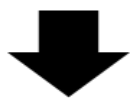

IMPLEMENTATION OF THE DRAFT BILL

- Meeting of the Working Committee and Formulation Team

- Discussing the initial draft prepared by The Legislative Service Agency

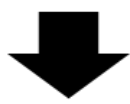

DECISION (in the meeting of commission)

- Work Team Presentation

- Decision Making and Signing of the proposed Bill

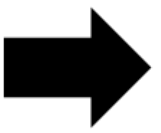

HEAD OF THE HOUSE OF REPRESENTATIVES

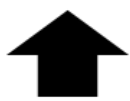

MEETING OF COMMISSION

- Final check

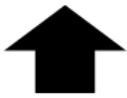

Legislative Body and The Legislative Service Agency

- Harmonization of the Bill

Figure 2. Recommendation Model of the Political Process in the Preparation of the Constitution of Oil and Gas in the People's Legislative Assembly of the Republic of Indonesia 